(C) В.Ю. Коваль, Е.Й. Архій, 2018

УДК 616.3(477.87):616.37-002-003.7-006.2

\title{
Структура захворювань підшлункової залози в гастроентерологічній патології на Закарпатті
}

\author{
В.Ю. Коваль, Е.Й. Архій \\ cowal.valya@ukr.net \\ Ужгородський національний університет, медичний факультет, кафедра пропедевтики \\ внутрішніх хвороб, Ужгород

\section{Реферат}

Вступ. Хвороби органів травлення в Україні займають третє місце серед усіх захворювань. Гострий панкреатит $\epsilon$ другою причиною по частоті госпіталізації, що робить найбільший внесок в загальні витрати і є п’ятою за частотою причиною смерті в стаціонарі.

Мета дослідження. Вивчити показники поширеності і захворюваності на усі хвороби, хвороби органів травлення та захворювань підшлункової залози, оперативних втручань на підшлунковій залозі у період 2014-2017 pp.

Матеріали та методи. Дані галузевої статистичної звітності - форма 12 за 2014-2017 роки.

Результати досліджень та їх обговорення. Виявлено зниження показників поширеності захворювань за всіма показниками за 2016-2017 роки. Показник поширеності усіх хвороб серед всього населення зменшився у 2017 році на 3,13\% порівняно з 2014 роком. Показник захворюваності усіх хвороб зменшився на 2,13\% у 2017 році порівняно 3 2014 роком. Виявлено зменшення показників захворюваності хвороб органів травлення на 11,32\% та поширеності на $8,55 \%$ у 2017 році порівняно з 2014 роком.

Висновки. У 2017 році порівняно з 2014 роком виявлено зниження показника поширеності усіх хвороб, хвороб органів травлення та хвороб підшлункової залози серед всього населення, в тому числі й у дітей віком від 0 до 17 років. У 2015-2016 роках виявлено зростання показника захворюваності серед всього населення, а в 2017 році спостерігається його зниження. Простежується тенденція до зростання показника захворюваності хвороб органів травлення у дітей віком від 0 до 17 років у 2016-2017 роках. Показник захворюваності на хвороби органів травлення має тенденцію до зниження у 2014-2017 роках як у дітей віком від 0 до 17 років, так і серед всього населення. Зменшення показника оперативних втручань та смертності з приводу захворювань підшлункової залози можливо пов'язано зі зниженням показників захворюваності та поширеності на захворювання підшлункової залози, в тому числі ускладнених форм.

Ключові слова: захворюваність, поширеність, смертність, хвороби підшлункової залози

The pancreatic disease structure in gastroenterological patology in Transcarpathia Koval V.Yu., Arkhii E.Yo.

Uzhhorod National University, Medical Faculty, Department of Propaedeutics of Internal Diseases, Uzhhorod

\section{Abstract}

Introduction. The digestive system diseases occupy the third place among all diseases in Ukraine. The second reason for the hospitalization frequency is acute pancreatitis, which makes the largest contribution to general expenses and is the fifth most frequent cause of death in hospital.

The purpose of the paper is to study the rates of prevalence and morbidity for all diseases, diseases of the digestive system and diseases of the pancreas, pancreas` surgical interventions during 2014-2017.

Materials and methods: research data of sectoral statistical reporting - form 12 during 2014-2017 years.

Research results and their discussion. The decrease in diseases prevalence by all indicators during 2016-2017 years was revealed. The diseases prevalence rate among the population decreased in 2017 by $3.13 \%$ compared to 2014 . The diseases incidence rate decreased by $2.13 \%$ in 2017 compared to 2014 . The decrease in the digestive system diseases incidence by $11.32 \%$ and the prevalence of $8.55 \%$ in 2017 compared to 2014 are revealed.

Conclusions. In 2017 compared with 2014 decrease in the diseases prevalence rate, digestive system diseases and diseases of the pancreas among the general population, including those in children from 0 to 17 years old, was found. In 2015-2016, an increase in the incidence rate among the entire population was detected, and in 2017 it was observed to decrease. There is a tendency to increase in the digestive system diseases incidence in children from 0 to 17 years in 20162017 years. The digestive system diseases incidence rate tends to decrease in the 2014-2017 years, both in children from 0 to 17 years old, and among the general population. The decrease in the number of surgical interventions and mortality from pancreatic diseases may be associated with decrease in the pancreatic diseases incidence and prevalence, including complicated forms.

Key words: morbidity, prevalence, mortality, pancreatic diseases

Вступ. Хвороби органів травлення (ХОТ) в Україні займають третє місце серед усіх захворювань. Основними нозологіями, що формують розповсюдженість та захворюваність ХОТ, є хронічний гастрит і дуоденіт, хронічний холецистит i холангіт, виразкова хвороба, хвороби підшлунко- вої залози. Основним чинником зростання показників став стрімкий розвиток комп'ютерних технологій, тобто завдяки впровадженню у практику нативної та ехоконтрастної гармоніки, тривимірної ехографії, адаптивного колорайзингу, ультразвукової ангіографії [1]. Спостерігається зростання 
захворюваності хвороб органів травлення - на 4,22\% у структурі захворюваності усього населення за основними класами у 2014 р. У структурі захворюваності населення в 2014 р. по відношенню до 2010 р. зросла питома вага наступних класів хвороб: хвороби нервової системи - на 6,6\%, що становить $2,42 \%$; хвороби органів травлення - на $4,2 \%$, що становить $4,22 \%$; хвороби сечостатевої системи - на $1,1 \%$, що становить $6,53 \%$; хвороби ока та його придаткового апарату - на 4,4\%, що становить 5,19\% [2]. Щорічна частота гострого панкреатиту коливається від 13 до 45 випадків на 100000 осіб [4]. Гострий панкреатит є другою причиною по частоті госпіталізації, що робить найбільший внесок в загальні витрати і є п`ятою за частотою причиною смерті в стаціонарі [5].

Мета дослідження. Вивчити показники поширеності і захворюваності на усі хвороби, хвороби органів травлення та захворювань підшлункової залози, оперативних втручань на підшлунковій залозі у період 2014-2017 pp.

Матеріали та методи. Матеріалами дослідження слугували дані галузевої статистичної звітності - форма 12 за 2014-2017 роки.

Результати досліджень та їх обговорення. За 2016-2017 роки спостерігається зниження показників поширеності захворювань за всіма показниками (табл. 1). Показник хвороби серед всього населення зменшився у 2016 році порівняно із 2015 роком на $0,59 \%$; у 2017 році порівняно із 2016 роком на 2,5\%. Виявлено незначне зростання показника усіх хвороб у дітей від 017 років у 2015 році порівняно 32014 роком на $1,6 \%$. У 2016 році порівняно 32015 роком та у 2017 році порівняно з 2016 роком виявлено зниження показника усіх хвороб серед дітей віком від 0-17 років - відповідно на $2,75 \%$ та $4,05 \%$. Показник хвороб органів травлення серед всього населення зменшився на 4,72\% у 2015 році порівняно з 2014 роком; на 4,3\% у 2016 році порівняно з 2015 роком; на 2,79\% у 2017 році порівняно 32016 роком. Також виявлено незначне зниження показника хвороб органів травлення у дітей віком від 0 до 17 років у 2014 порівняно 3 2017 роком - на 7,1\%. Поступове зниження показника поширеності на захворювання підшлункової залози виявлено серед дорослого населення та у дітей віком від 0 до 17 років у 2014-2017 роках. У 2017 році порівняно з 2014 роком виявлено зниження показника поширеності хвороб підшлункової залози серед всього населення на $7,1 \%$. Поширеність на хвороби підшлункової залози у дітей віком від 0 до 17 років зменшилась на $17,2 \%$.

Показники поширеності захворювань у Закарпатській області

Таблиця 1

\begin{tabular}{|l|c|c|c|c|c|c|c|}
\hline \multicolumn{1}{|c|}{ Показники } & 2014 рік & 2015 рік & $\begin{array}{c}2016 \\
\text { рік }\end{array}$ & $\begin{array}{c}2017 \\
\text { рік }\end{array}$ & $\begin{array}{c}\text { 3міни } \\
2014 / 2015\end{array}$ & $\begin{array}{c}\text { 3міни } \\
2015 / 2016\end{array}$ & $\begin{array}{c}\text { 3міни } \\
\text { 2016/2017 }\end{array}$ \\
\hline $\begin{array}{l}\text { Усі хвороби (серед } \\
\text { всього населення), на } \\
100000\end{array}$ & 159324,8 & 158506,1 & 157577,1 & 154351,6 & $-818,7$ & -929 & $-3225,5$ \\
\hline $\begin{array}{l}\text { Усі хвороби (діти 0-17 } \\
\text { років), на 1000 насе- } \\
\text { лення }\end{array}$ & 1334,10 & 1355,76 & 1318,5 & 1265,11 & $+21,66$ & $-37,26$ & $-53,39$ \\
\hline $\begin{array}{l}\text { ХОТ (серед всього } \\
\text { населення), на 100000 } \\
\text { населення }\end{array}$ & 17542 & 16714,5 & 16002,6 & 15557,7 & $-827,5$ & $-711,9$ & $-444,9$ \\
\hline $\begin{array}{l}\text { ХОТ (діти 0-17 років), } \\
\text { на 1000 населення }\end{array}$ & 92,52 & 91,48 & 89,69 & 89,41 & $-1,04$ & $-1,79$ & $-0,28$ \\
\hline $\begin{array}{l}\text { Захворювання ПЗ (се- } \\
\text { ред всього населення), } \\
\text { на 100000 населення }\end{array}$ & 1799,9 & 1760,4 & 1728,9 & 1673,9 & $-39,5$ & $-31,5$ & -55 \\
\hline $\begin{array}{l}\text { Захворювання П3 (діти } \\
\text { 0-17 років), на 1000 } \\
\text { населення }\end{array}$ & 3,08 & 2,98 & 2,74 & 2,55 & $-0,1$ & $-0,24$ & $-0,19$ \\
\hline
\end{tabular}

Показник захворюваності усіх хвороб серед всього населення зріс у 2015 році на $0,84 \%$ порівняно 3 2014 роком та у 2016 році на $0,94 \%$ порівняно з 2015 роком (табл. 2). У 2017 році у порівнянні з 2016 роком даний показник зменшився на 3,9\%. У 2015 році у порівнянні з 2014 роком показник захворюваності усіх хвороб у дітей віком від 0 до 17 років зріс на 2,21\%. У 2016-2017 роках спостерігається тенденція до зниження даного показника - на 4,3\% - 5,36\%.
Захворюваність хвороб органів травлення серед всього населення зменшився у 2017 році порівняно 3 2014 роком на 8,55\%, однак відзначено зростання захворюваності хвороб органів травлення у дітей віком від 0 до 17 років на 2,72\% у 2017 році в порівнянні з 2015 роком. Показник захворюваності хвороб підшлункової залози зменшився серед всього населення і також у дітей віком від 0 до 17 років у 20142017 роках - відповідно на 10,06\% та 16,76\%. 
Показники захворюваності у Закарпатській області

\begin{tabular}{|l|c|c|c|c|c|c|c|}
\hline \multicolumn{1}{|c|}{ Показники } & $\begin{array}{c}2014 \\
\text { рік }\end{array}$ & $\begin{array}{c}2015 \\
\text { рік }\end{array}$ & $\begin{array}{c}2016 \\
\text { рік }\end{array}$ & $\begin{array}{c}2017 \\
\text { рік }\end{array}$ & $\begin{array}{c}\text { 3міни } \\
2014 / 2015\end{array}$ & $\begin{array}{c}\text { 3міни } \\
2015 / 2016\end{array}$ & $\begin{array}{c}\text { 3міни } \\
2016 / 2017\end{array}$ \\
\hline $\begin{array}{l}\text { Усі хвороби (серед всього } \\
\text { населення), на 100000 } \\
\text { населення }\end{array}$ & 60007,7 & 60515,1 & 61084,6 & 58729,9 & $+507,4$ & $+569,5$ & $-2354,7$ \\
\hline $\begin{array}{l}\text { Усі хвороби (діти 0-17 } \\
\text { років), на 1000 населення }\end{array}$ & 959,11 & 980,31 & 938,10 & 887,85 & $+21,2$ & $-42,21$ & $-50,25$ \\
\hline $\begin{array}{l}\text { ХОТ (серед всього насе- } \\
\text { лення), на 100000 населен- } \\
\text { ня }\end{array}$ & 4527,5 & 4229,4 & 4202,7 & 4140,5 & $-298,1$ & $-26,7$ & $-62,2$ \\
\hline $\begin{array}{l}\text { ХОТ (діти 0-17 років), } \\
\text { на 1000 населення }\end{array}$ & 57,8 & 57,37 & 57,94 & 58,93 & $-0,43$ & $+0,57$ & $+0,99$ \\
\hline $\begin{array}{l}\text { Захворювання П3 } \\
\text { (серед всього населення), } \\
\text { на 100000 населення }\end{array}$ & 221,7 & 209,6 & 200,7 & 199,4 & $-12,1$ & $-8,9$ & $-1,3$ \\
\hline $\begin{array}{l}\text { Захворювання П3 } \\
\text { (діти 0-17 років), на 1000 } \\
\text { населення }\end{array}$ & 1,73 & 1,68 & 1,59 & 1,44 & $-0,05$ & $-0,09$ & $-0,15$ \\
\hline
\end{tabular}

Найбільше оперативних втручань на підшлунковій залозі (ПЗ) було виконано в 2015 році (рис. 1). У 2016-2017 роках спостерігається тенденція до зменшення оперативних втручань 3 приводу захворювань підшлункової залози. Виявлено зменшення смертності від оперативних втручань на підшлунковій залозі порівняно з 2016 роком на 2,8\% (рис. 2).

Найвищу смертність від оперативних втручань на підшлунковій залозі виявлено в 2015 році 10,84\% (рис. 2). У 2017 році виявлено найнижчий показник смертності від оперативних втручань на підшлунковій залозі - 7,27\%.

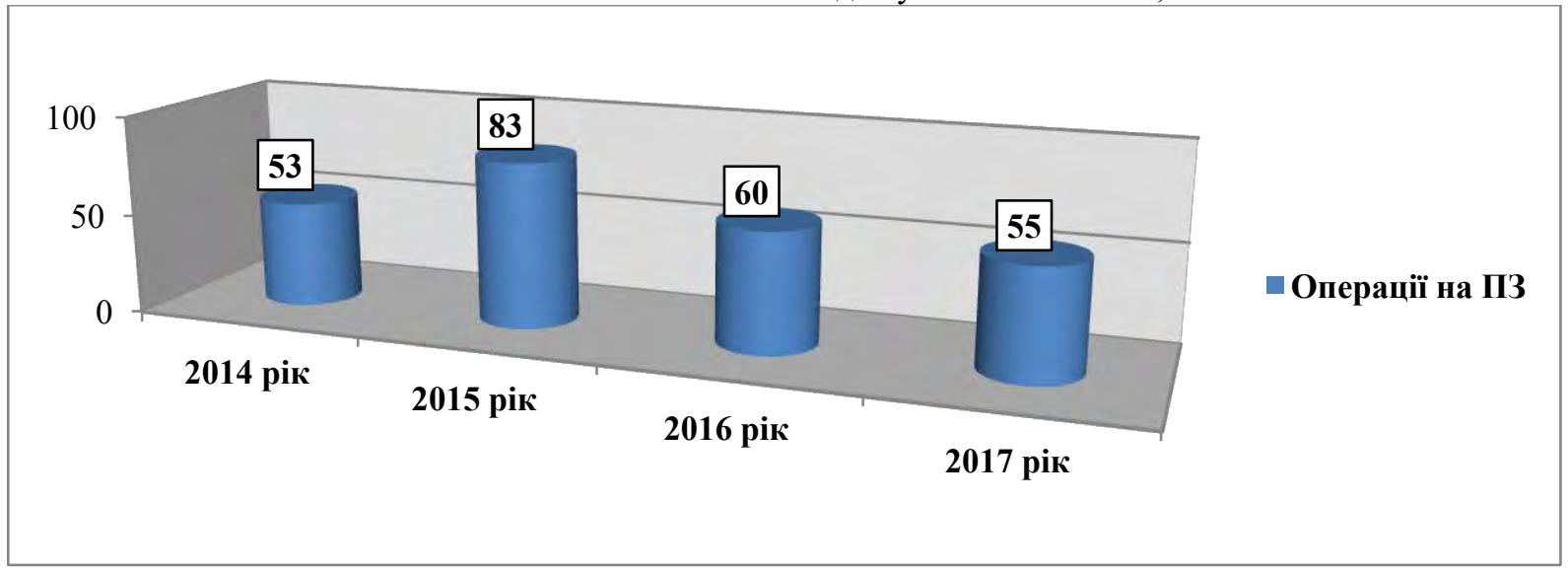

Рис. 1. Операції на ПЗ

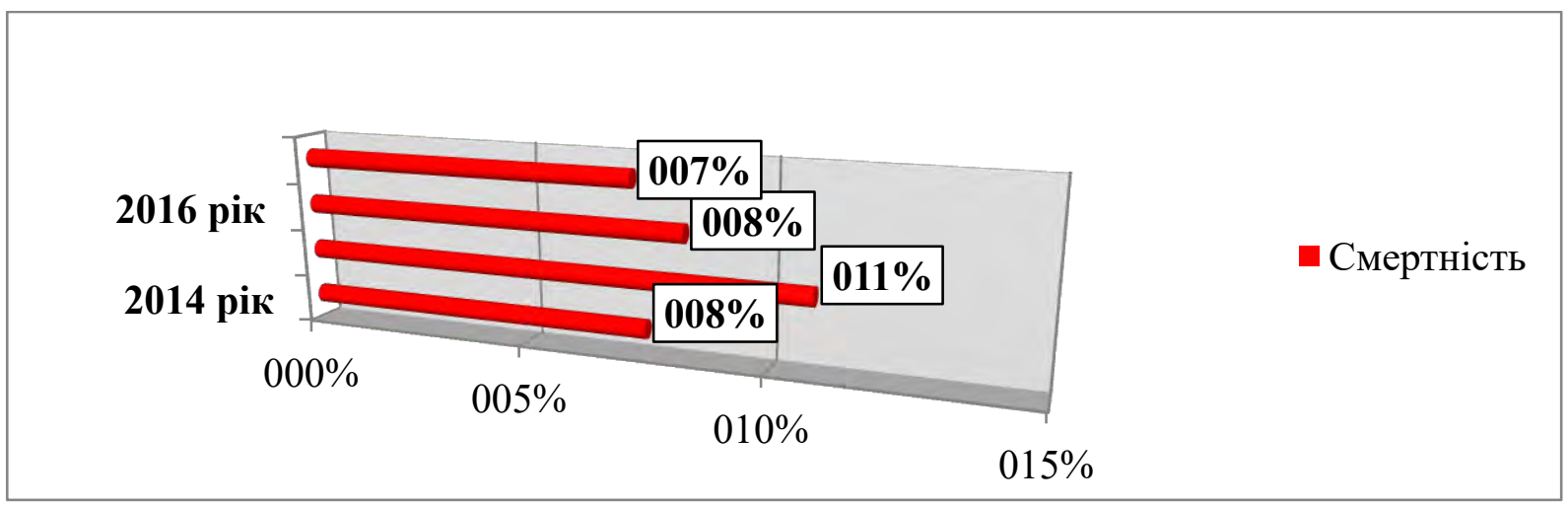

Рис. 2. Смертність 
Висновки. 1. У 2017 році порівняно з 2014 роком виявлено зниження показника поширеності усіх хвороб, хвороб органів травлення та хвороб підшлункової залози серед всього населення, в тому числі й у дітей віком від 0 до 17 років.

2. У 2015-2016 роках виявлено зростання показника захворюваності серед всього населення, а в 2017 році спостерігається його зниження.

3. Спостерігається тенденція до зростання показника захворюваності хвороб органів трав- лення у дітей віком від 0 до 17 років у 20162017 роках

4. Показник захворюваності на хвороби органів травлення має тенденцію до зниження у 2014-2017 роках як у дітей віком від 0 до 17 років, так і серед всього населення.

5. Зменшення показника оперативних втручань та смертності з приводу захворювань підшлункової залози можливо пов'язано із зниження показників захворюваності та поширеності на захворювання підшлункової залози, в тому числі ускладнених форм.

Інформація про конфлікт інтересів. Автори заявляють про відсутність конфлікту інтересів при виконанні наукового дослідження та підготовці даної статті.

Інформація про фінансування. Автори гарантують, що вони не отримували жодних винагород в будь-якій формі, здатних вплинути на результати роботи.

Особистий внесок кожного автора у виконання роботи:

Архій Е.Й. - розробка концепції і дизайну дослідження, аналіз отриманих даних, редагування;

Коваль В.Ю. - збір матеріалу, статистична обробка даних, підготовка тексту.

\section{Список використаної літератури}

1. Stepanov YM. Khvoroby orhaniv travlennia ta hastroenterolohichna dopomoha naselenniu Ukrainy: zdobutky, problemy ta shliakhy yikh vyrishennia. Zdorov`ia Ukrainy. 2014;9:10-11. [In Ukrainan].

2. Znamenska MA, Slabkyi HO. Analiz zakhvoriuvanosti ta poshyrenosti khvorob sered naselennia Ukrainy. Neonatolohiia, khirurhiia ta perynatalna medytsyna. 2015;3(17):24-29. [In Ukrainan].

3. Smirnova VL, Panchyshyn NY, Lytvynova ON. Porivnialnyi analiz osnovnykh pokaznykiv zakhvoriuvanosti naselennia Ternopilskoi oblasti. Visnyk sotsialnoi hihiieny ta orhanizatsii okhorony zdorov`ia. 2014;4(62):41-44. [In Ukrainan].

4. Yadav D., Lowenfels A.B. The epidemiology of pancreatitis and pancreatic cancer. Gastroenterology. 2013 Jun;144(6):1252-61.

5. Lankisch PG, Apte M, Banks PA. Acute pancreatitis. The Lancet. Jul 4;386(9988):85-96. DOI: $10.1016 / \mathrm{S} 0140-6736(14) 60649-8$

Стаття надійшла до редакції: 17.01.2018 р. 